\title{
Protein enrichment of cassava residue using Trichoderma pseudokoningii (ATCC 26801)
}

\author{
Richard Bayitse ${ }^{1 *}$, Xiaoru Hou $^{2}$, Gabriel Laryea ${ }^{1}$ and Anne-Belinda Bjerre ${ }^{2}$
}

\begin{abstract}
Solid state fermentation of cassava residue with Trichoderma pseudokoningii was conducted for 12 days. The fermentation was carried out at temperature of $24^{\circ} \mathrm{C}$ and a pH of 5.0. Urea and ammonium sulphate were used as nutrient sources and moisture content varied at 60 and $70 \%$. Protein content of the unfermented cassava residue was increased from 8.4 to $12.5 \%$ when urea was used with initial moisture content of $70 \% \mathrm{~W} / \mathrm{v}$. This study showed that a maximum of $48.1 \%$ protein enrichment was achieved using urea as a source of nutrient for the growth of the fungi, whiles ammonium sulphate achieved $36.9 \%$ protein enrichment under the same condition.
\end{abstract}

Keywords: Fermentation, Solid State, Protein, Cassava waste

\section{Introduction}

The use of agro-industrial residues such as coffee pulp and husk, cassava bagasse, sugarcane bagasse, sugar beet pulp, apple pomace, declassified potatoes for efficient utilisation in value-added products has gained prominence in recent years (Ashok Pandey and Soccol 2000; Soccol and Vandenberghe 2003).

Cassava is grown in Tropical Africa, South and Central America and consumed by most people in these countries. Over the years, fermentation has been carried on cassava to produce similar or different products which are mostly associated with residue products (Akinrele 1967; Onilude 1996). Cassava peels; leaves and starch residues constitute $25 \%$ of the cassava plant which are usually discarded as wastes after harvesting and processing, with limited utilization due to low protein, high crude fibre and cyanide contents (Iyayi and Losel 2001; Onilude 1996). Among these cassava peel is noted to be the highest and is heaped in production areas with accompanying smelly odours (Ezekiel and Aworh 2013).

Cassava is one of the most important tubers cultivated in Ghana and accounts for a daily calorie intake of $30 \%$, is grown by almost every farming family (FAO 2014) and is cultivated in almost every region in Ghana. Large

\footnotetext{
*Correspondence: rbayitse@gmail.com

${ }^{1}$ Council for Scientific and Industrial Research/Institute of Industrial

Research, P.O Box LG 576, Legon, Ghana

Full list of author information is available at the end of the article
}

quantities are produced in the south and middle part of Ghana, which accounts for approximately $78 \%$ of the total cassava production in Ghana. Cassava production has increased over the years from 8,966,000 MT in 2001 to $14,240,000 \mathrm{MT}$ in 2011 (SRID-MoFA 2011). Currently, Nkwanta South District is the largest producer of cassava in Ghana accounting for some 712,000 MT in 2011 (Bayitse et al. 2013).

Cassava is usually processed to obtain different relatively shelf stable intermediate and final products. Most of the cassava processing in Ghana is rural based and dominated by women. A traditional method (i.e. hand peeling) and also small scale industrial processing machines are also used. In 2011, 14,240,000 MT of cassava was produced and processed, out of which generated $3,802,080$ MT of cassava peels (Bayitse et al. 2013). Peels normally consist of the thin pericarp and the thicker ring. Most processes remove both the pericarp and the thicker ring along with some pulp adhered to the peels. Analysis of the chemical composition of cassava peels indicates the following: dry matter $86.5-94.5 \%$; organic matter 81.9-93.9 \%; crude protein 4.1-6.5\%; hemicellulose and cellulose $34.4 \%$; and lignin $8.4 \%$ (Kongkiattikajorn and Sornvoraweat 2011).

Cellulosic materials can be converted to protein by cellulolytic microbes thereby improving their protein contents. The application of these microbes in solid state fermentation (SSF) for protein improvement increases

\section{Springer}


the application values of cellulosic materials (Gélinas and Barrette 2007; Ugwuanyi et al. 2008). The process for converting these materials to animal feed is a potential issue. Recently, the use of cellulolytic microbes to covert cellulosic materials to non-ruminants feeds was an important issue in animal husbandry (Robinson and Nigam 2003). The economic value of biotechnological production of protein-enriched products can be enhanced if the needed carbon source (glucose) could be obtained from lowcost lignocellulosic waste, using SSF (Ezekiel and Aworh 2013). Nitrogen supplementation of the raw substrate in SSF may stimulate microbial growth or improve process efficiency and can play an important role not only as nutritive compounds but also can influence $\mathrm{pH}$ changes during the process (Correia et al. 2007).

Lignocellulose degrading fungi are used in industrial scale, mostly for the production of cellulases, xylanases, and for biopulping. Most investigated, used and genetically improved are fungi of Trichoderma spp (Himmel et al. 1999). Trichoderma species are very efficient in producing many extracellular enzymes and are mostly used in the food and textile industries to degrade complex polysaccharides (Ezekiel and Aworh 2013). The occurrence of pathogenic Trichoderma strains may be restricted to species of section Longibrachiatum; the species in this section are Trichoderma longibrachiatum and Trichoderma citrinoviride (Kuhls et al. 1999).

Ghana produces large quantities of agricultural waste that can be converted into food, feed, energy or industrial products for domestic use. The over 2 million MT of maize stalks, 0.5 million of maize cob and 3.8 million MT of cassava peel produced per annum in Ghana are examples of conventional feed stocks which can be converted to protein rich material through SSF, which can be used to formulate animal feed especially for the poultry and fish production sectors. For instance in Ghana the poultry industry imports about 53,000 MT of feed annually which causes over US $\$ 32$ million (GCNET-MOTI 2014). Increasing value-added processing of agricultural wastes in Ghana will improve the demand for agricultural waste utilisation, increase farm profitability, provide jobs, produce protein material for feed processing industries and help minimise rural urban drift.

This research is aimed at improving the protein content of cassava residue by SSF using Trichoderma pseudokoningii (ATCC 26801).

\section{Materials and methods Feedstock}

Cassava residue was sampled from a small scale cassava processing plant from Bawjiase, Ghana. The residue is composed of cassava peel mixed with cassava trimmings. The cassava residue was soaked in water and cleaned by removing the brown outer skin, dried at $60{ }^{\circ} \mathrm{C}$ overnight, and milled (sizes of milled particles: $74 \%$ of particles were $<0.25 \mathrm{~mm}$ and $26 \%$ of particles were $>0.25$ and $<0.45 \mathrm{~mm}$ in diameter).

\section{Cassava residue composition analysis}

Dry matter content (DM) of the sample was measured by weighing the samples before and after overnight drying at $105^{\circ} \mathrm{C}$ in an oven. Ash content was determined by weighing before and after ashing at $550{ }^{\circ} \mathrm{C}$ for two hours in Muffle Furnace.

Protein content was measured in Eurofins Steins Laboratorium A/S (Denmark) by measuring the total nitrogen content using Dumas method. The protein content was afterwards calculated by multiplying the total nitrogen content of the sample with a factor of 6.25.

Total starch analysis was carried out using Megazyme starch assay kit based on the use of thermostable $\alpha$-amylase and amyloglucosidase (McCleary et al. 1997; Megazyme International 2014). This method has been adopted by AOAC (Official Method 996.11) and AACC (Method 76.13.01).

\section{Microorganism}

Trichoderma pseudokoningii (ATCC 26801) was purchased from LGC Standards.

\section{Inoculum preparation}

The vial containing freeze dried Trichoderma pseudokoningii (ATCC 26801) was opened and $1 \mathrm{ml}$ of sterile distilled water was added and stirred to form a suspension. The suspension was transferred aseptically to $5 \mathrm{ml}$ of sterile distilled water in sterile test tube. This was then incubated at room temperature $\left(25^{\circ} \mathrm{C}\right)$ for $2 \mathrm{~h}$ undisturbed. The suspension was mix well for subculture preparation.

\section{Subculture preparation}

The malt extract agar was sterilised with $20 \mu \mathrm{L}$ of $200 \mathrm{mg} / \mathrm{L}$ Ampicillin to kill any possible bacteria before 2 drops of inoculum was put on the malt extract agar in a petri dish, spread to cover the surface with sterile inoculation loop under aseptic condition and incubated at $24{ }^{\circ} \mathrm{C}$ for 5 days. Spores were harvested into sterile deionized water forming about $3 \times 10^{7}$ of spore suspension per $\mathrm{ml}$.

\section{Solid state fermentation (SSF)}

$30 \mathrm{~g}$ of cassava residue sample was weighed into $250 \mathrm{ml}$ conical flasks in duplicates. $0.3 \mathrm{~g}$ of Urea and Ammonium Sulphate were added separately to the samples to provide different types of nutrient for the Trichoderma pseudokoningii growth. Moisture contents of the samples were 
adjusted to $60 \% \mathrm{w} / \mathrm{v}$ and $70 \% \mathrm{w} / \mathrm{v}$ respectively with distilled water and the moisture content was determined by Moisture Analyzer (Mettler Toledo, MJ33). The $\mathrm{pH}$ was adjusted to 5.0-5.4 using $0.1 \mathrm{M} \mathrm{HCl}$. The mouth of the flasks was covered with aluminium foil. The flasks containing the samples were autoclaved at $121{ }^{\circ} \mathrm{C}$ for $15 \mathrm{~min}$ and allowed to cool to ambient temperature. The samples were inoculated with $2 \mathrm{ml}$ of spore suspension prepared from the subculture and fermented at $24{ }^{\circ} \mathrm{C}$ for 12 days. Samples were taken aseptically at 2 days intervals and dried at $80{ }^{\circ} \mathrm{C}$ for $24 \mathrm{~h}$. Protein content was measured in Eurofins Steins Laboratorium A/S (Denmark) by measuring the total nitrogen content using Dumas method. The protein content was afterwards calculated by multiplying the total nitrogen content of the sample with a factor of 6.25. The data was analysed with excel.

\section{Results}

\section{Biomass composition}

The analysis of chemical composition of cassava residue is given in Table 1 . The residual starch of the cassava waste was $47.2 \%$. The protein was $5.16 \%$ and $9.3 \mathrm{mg} / \mathrm{kg}$ cyanide was measured.

\section{Cassava residue particle sizes}

The sieve analysis of the cassava residue recorded particle sizes of $74 \%<0.25 \mathrm{~mm}$ and $26 \%$ were $>0.25$ and $<0.45 \mathrm{~mm}$ in diameter.

\section{Effect of initial moisture content}

Two different moisture contents $(60 \% \mathrm{w} / \mathrm{v}$ and $70 \% \mathrm{w} / \mathrm{v})$ were used in the experiment. Among the two, $70 \% \mathrm{w} / \mathrm{v}$

Table 1 Chemical composition of cassava residue

\begin{tabular}{lccccc}
\hline Sample & DM (\%) & $\begin{array}{l}\text { Ash }(\% \\
\text { DM) }\end{array}$ & $\begin{array}{l}\text { Starch (\% } \\
\text { DM) }\end{array}$ & $\begin{array}{l}\text { Protein } \\
(\% \text { DM) }\end{array}$ & $\begin{array}{l}\text { Cyanide } \\
\text { (mg/kg) }\end{array}$ \\
\hline $\begin{array}{l}\text { Cassava } \\
\text { waste }\end{array}$ & $89.7 \pm 0.1$ & $6.3 \pm 0.3$ & $47.2 \pm 3.2$ & $5.16 \pm 0.39 .30 \pm 0.42$ \\
\hline
\end{tabular}

Mean values with standard deviations recorded higher protein enrichment of $12.50 \%$ when urea was used as initial nitrogen source; $8.89 \%$ when ammonium sulphate was used and $6.37 \%$ when no nitrogen was used over a period of 12 days of SSF with Trichoderma pseudokoningii (ATCC 26801) as compared to $11.82 \%$ protein when urea was used as initial nitrogen source; $8.24 \%$ using ammonium sulphate and $6.08 \%$ with no nitrogen treatment at $60 \% \mathrm{w} / \mathrm{v}$ moisture (Table 2).

\section{Protein enrichment of cassava waste after SSF}

The improvement in nitrogen composition of the fermented cassava residue over 12 days is presented in Table 2. The result showed the effect of solid state fermentation with Trichoderma pseudokoningii (ATCC 26801) on protein content of cassava residue samples. The crude protein increased from $5.17 \%$ in unfermented samples to $6.37 \%$ in fermented samples for cassava residue without any nutrient treatment. This accounted for only $23.34 \%$ increase in protein enrichment over 12 days of SSF (Table 2; Fig. 1). Addition of urea and ammonium sulphate have improved protein content of the cassava residue as compared with samples without nutrient addition. Treatment with urea at $70 \%$ moisture recorded the highest protein content of $12.50 \%$ which showed an improvement of $48.15 \%$ over a period of 12 days as compared to 8.89 with $36.87 \%$ improvement over the SSF period using ammonium sulphate as nutrient source (Table 2; Fig. 1).

\section{Discussions}

The high residual starch of cassava residue from the composition analysis could partly be attributed to the peeling process of cassava tuber which normally leaves some amount of the flesh which contains starch as well as the trimmings which are also starchy (Table 1). The total cyanide content of cassava parenchyma depends on the variety, the environment and various other factors. Cyanide levels of between 1 and $1500 \mathrm{ppm}$ can be recorded (Bokanga 1994). The low cyanide content could be due to the variety of cassava (Afisiafi) as well as the pretreatment process involving soaking in water to leach out

Table 2 Protein content (\%) of cassava waste after varying treatments

\begin{tabular}{|c|c|c|c|c|c|c|}
\hline \multirow[t]{3}{*}{ Days } & \multicolumn{6}{|l|}{ Treatments } \\
\hline & \multicolumn{2}{|l|}{ Urea } & \multicolumn{2}{|c|}{ Ammonium Sulphate } & \multicolumn{2}{|l|}{ No nutrient } \\
\hline & $60 \% \mathrm{w} / \mathrm{v}$ moisture & $70 \% \mathrm{w} / \mathrm{v}$ moisture & $60 \% \mathrm{w} / \mathrm{v}$ moisture & $70 \% \mathrm{w} / \mathrm{v}$ moisture & $60 \% \mathrm{w} / \mathrm{v}$ moisture & $70 \% \mathrm{w} / \mathrm{v}$ moisture \\
\hline 0 & $8.13 \pm 0.44$ & $8.44 \pm 0.00$ & $6.52 \pm 0.00$ & $6.50 \pm 0.00$ & $5.18 \pm 0.00$ & $5.17 \pm 0.00$ \\
\hline 6 & $9.01 \pm 0.00$ & $9.94 \pm 0.44$ & $7.05 \pm 0.00$ & $7.10 \pm 0.00$ & $5.17 \pm 0.00$ & $5.16 \pm 0.00$ \\
\hline 12 & $11.82 \pm 0.44$ & $12.50 \pm 0.44$ & $8.24 \pm 0.00$ & $8.89 \pm 0.00$ & $6.08 \pm 0.44$ & $6.37 \pm 0.00$ \\
\hline
\end{tabular}

Mean values with standard deviations 


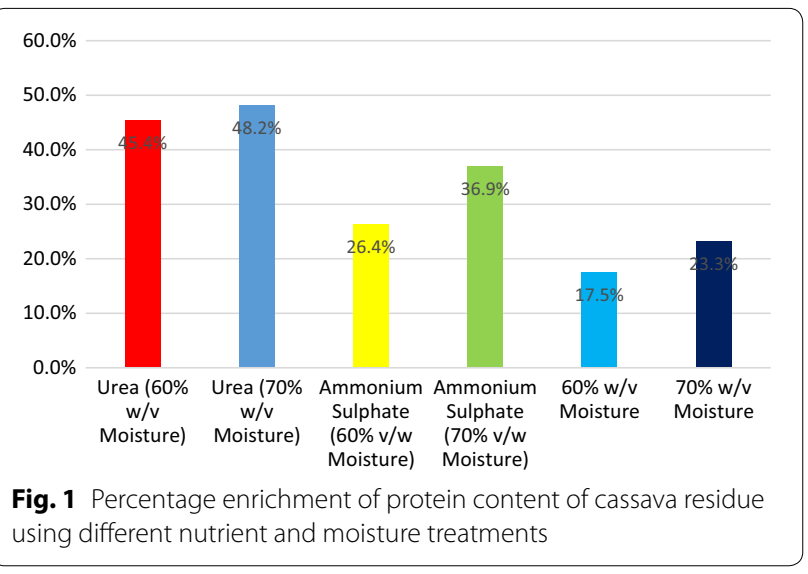

some of the cyanide followed by drying at $60^{\circ} \mathrm{C}$ for $24 \mathrm{~h}$ before milling. Attahdaniel et al. (2013) reduced cyanide level in cassava peel from $268 \mathrm{mg}$ to $140 \mathrm{mg}$ by drying. Tewe and Iyayi (1989) also reduced cyanide in cassava peel from 364.2 to $814.7 \mathrm{ppm}$ to $264.3-321.5 \mathrm{ppm}$ by sun drying and also confirmed that the peel of "bitter" cassava variety was shown to contain $650 \mathrm{ppm}$ whiles the "sweet" variety contained an average of $200 \mathrm{ppm}$. Cyanide levels up to $1600 \mathrm{mg} / \mathrm{kg}$ have been reported in untreated cassava peel (Tivana 2012). The low cyanide content reduces the risk of fermentation inhibition which is normally associated with cassava peel as a result of high level of toxic cyanogenic glycosides (Ofoefule and Uzodinma 2009).

Particle size had a profound effect on biomass and protein production in SSF. Smaller particle sizes provide a greater saturated surface area but a lower porosity within the particles than larger particles (Camacho-Ruiz et al. 2003). Larger particles provide better aeration/respiration opportunities but provide lesser surface area which does not encourage the growth of the filamentous organism (Pandey 1992). The blend of particle sizes is promising to address the problems of aeration and surface area. An optimal particle size of $5 \mathrm{~mm}$ for biomass production in Saccharomyces cerevisiae on sugarcane baggase has been reported as well as from cassava peels with 3.35$4.00 \mathrm{~mm}$ using Trichoderma viride (Camacho-Ruiz et al. 2003; Ezekiel and Aworh 2013).

Moisture content of substrates is not entirely dependent on the environmental conditions. It is known that wood-inhabiting fungi can influence the microclimatic regime in dead wood (Tudor et al. 2012). Some fungi are able to regulate the moisture content of a substrate to ensure the optimal water availability. During the initial stages of colonization, the dry conditions are improved for optimal growth by means of cellulose and polysaccharide decomposition, while at higher levels of humidity the water surplus is extracted from the substrate into aerial mycelium, to ensure the optimal moisture content (Tudor et al. 2012). Solid state fermentation allows the manipulation of moisture in order to adjust this parameter to a particular requirements by fungal strain. The reduction in protein content with $60 \% \mathrm{w} / \mathrm{v}$ moisture could be due to insufficient water which did not allow good diffusion of solutes and gas, thereby slowing cell metabolism because of a lack of substrates or through too high concentration of inhibitive metabolites in or near the cell (Gervais and Molin, 2003). High initial moisture content of more than $70 \%$ has been reported by Ezekiel and Aworh (2013) to produce less protein in SSF using Trichoderma viride (ATCC 36316) which was attributed to the steric hindrance of the growth of Trichoderma viride. This can be caused by compaction of the substrate, reduction in porosity of the solid matrix and consequent interference with oxygen transfer.

Using Trichoderma species, maximum reduction of starch in cassava residue was observed during the first 12 days (Balagopalan 1996). This period is also known for optimum sugar and protein levels (Ezekiel and Aworh 2013). The range of carbon source utilised for mycelial growth of different fungi is very wide. Monosaccharides, disaccharides and polysaccharides can be used as suitable carbon sources (Nagadesi and Arya 2013). The study with Trichoderma pseudokoningii increased protein levels in the cassava residue for all treatments which confirms its ability to secrete enzymes such as amylolytic and cellulolytic enzymes to break down starch and non-starch polysaccharides to monomer sugars which are easily metabolized to protein (Ezekiel and Aworh 2013; Balagopalan 1996). Addition of exogenous nitrogen sources increased protein enrichment during fermentation of cassava residue with Trichoderma pseudokoningii (ATCC 26801) (Fig. 1). This agrees with the observations of Roussos et al. (1993) and Ezekiel and Aworh (2013) on the effect of nitrogen supplementation on fungal species. Urea as a nitrogen source has been utilised better by Aspergillus oryzae as compared with other sources (Duru and Uma 2003). Ezekiel and Aworh (2013) reported that ammonium sulphate was more effectively used by Trichoderma viride (ATCC 36316) than Urea.

However, in this study urea was utilized efficiently as compared to ammonium sulphate as a nitrogen source in protein production. This could be due to high nitrogen content of urea which is about $46 \%$ as compared to $21 \%$ in ammonium sulphate. The use of urea as initial nutrient source has increased protein enrichment by $96.2 \%$ compared to sample without initial nutrient source. This essential element is used by fungi for functional as well as structural purposes. Chitin, the chief component of cell wall in most of the fungi, is a linear polymer of D-glucoseamine. Similarly proteins, the basis of protoplasm 
are composed of nitrogenous substance. Purines, pyrimidines, some vitamins and other essential metabolites are also nitrogen containing compounds. Naturally, both the organic and inorganic forms of nitrogen are available to fungi but as far as their utilization is concerned they fundamentally differ from each other in their metabolic potentialities (Nagadesi and Arya 2013).

Protein enrichment studies have been conducted on food residue such as cassava peel, pineapples and cocoyam using Saccharomyces cerevisae and Aspergillus oryzae (Duru and Uma 2003; Ezekiel and Aworh 2013; Aggelopoulos et al. 2014). Protein enrichment effect of Trichoderma pseudokoningii on cassava residue is better as compared to Trichoderma viride in an experiment conducted by Ezekiel and Aworh (2013) on cassava peel. Iyayi and Losel (2001) in their work reported an increase in protein content of cassava peel from 5.6 to $14.4 \%$ when Aspergillus niger was used in SSF for 20 days which was increased to $16.74 \%$ when fermented with Saccharomyces cerivisiea.

In conclusion, fermentation of cassava residue with Trichoderma pseudokoningii for 12 days could enrich the protein content by $48.2 \%$ when urea was used as a source of nutrient and the moisture of the substrate was adjusted to $70 \% \mathrm{w} / \mathrm{v}$. About $20 \%$ of cassava waste is only used to feed goats and sheep in Ghana because of its low protein content. From these findings, feed manufacturers will be encouraged to utilize plant proteins more efficiently to produce low-cost product for animal husbandry.

\section{Authors' contributions \\ $\mathrm{RB}, \mathrm{XH}$ and $\mathrm{ABB}$ have designed the work. $\mathrm{RB}$ and $\mathrm{XH}$ carried out the experi- ment. $R B, X H, A B B$ and $G L$ analysed the data. RB wrote the manuscript. $R B$, $X H, A B B$ and $G L$ reviewed the manuscript and made very important scientific contributions. All authors read and approved the final manuscript.}

\section{Author details}

${ }^{1}$ Council for Scientific and Industrial Research/Institute of Industrial Research, P.O Box LG 576, Legon, Ghana. ${ }^{2}$ Danish Technological Institute, Gregersensvej 1, Taastrup 2630, Denmark.

\section{Acknowledgements}

The authors are very thankful to European Union (EU) for funding the study through European Commission's Seventh Framework Programme for Research and Technological Development (FP7/2007-2013) Biowaste 4SP Grant Agreement Nr. 312111.

\section{Competing interests}

The authors declare that they have no competing interests.

Received: 5 November 2015 Accepted: 11 December 2015 Published online: 22 December 2015

\section{References}

Aggelopoulos T, Katsieris K, Bekatorou A, Pandey A, Banat IM, Koutinas AA. Solid state fermentation of food waste mixtures for single cell protein, aroma volatiles and fat production. Food Chem. 2014;145:710-6. doi:10.1016/j.foodchem.2013.07.105
Akinrele IA. Further studies on the fermentation of cassava. Research. Report No.20 of the Federal Institute of Industrial Research, Oshodi, Nigeria. 1967. Attahdaniel BE, Adeeyinwo CE, Adetunji AR, Olusunle SOO, Adewoye OO. Performance characteristics of argentometric method of cyanide determination. Int J Sci Technol. 2013;2(10):735-40.

Balagopalan C. Improving the nutritional value of cassava by solid state fermentation: CTCRI experiences. J Sci Ind Res. 1996;5:479-82.

Bayitse R, Oduro W, Aggey M, Selormey G, Mensah B, Laryea G. Overview of potential biowaste and biobased residues for production of value added products. Ghana Country Report for FP7 Biowaste4SP, Grant Agreement No. 312111, 2013

Bokanga M. Distribution of cyanogenic potential in the cassava germplasm. Acta Horticul. 1994;375:117-23.

Camacho-Ruiz L, Perez-Guerra N, Roses R. Factors affecting the growth of Saccharomyces cerevisea in batch culture and in solid state fermentation. Elec J Env Agric Food Chem. 2003;2(5):531-42.

Correia R, Magalhães M, Macêdo G. Protein enrichment of pineapple waste with Saccharomyces cerevisiae by solid state bioprocessing. J Sci Ind Res. 2007;66(March):259-62.

Duru CC, Uma NU. Protein enrichment of solid waste from cocoyam (Xanthosoma sagittifolium(L.)Schott) cormel processing using Aspergillus oryzae obtained from cormel flour. African J Biotechnol. 2003;2(8):228-32.

Ezekiel OO, Aworh OC. Solid State Fermentation of Cassava Peel with Trichoderma viride (ATCC 36316) for Protein Enrichment. Inter J Biol Food Vet Agric Eng. 2013; 7(Atcc 36316): 667-74

FAO. A review of cassava in Africawith country case studies on Nigeria, Ghana,the United Republic of Tanzania, Uganda and Benin. Retrieved December 22, 2014, from http://www.fao.org/docrep/009/a0154e/ A0154E01.htm. 2000.

GCNET-MOTI. Poultry Feed Importation Figures. Research Statistics and Information Management, Ministry of Trade and Industry, Ghana, Accra. 2014

Gélinas P, Barrette J. Protein enrichment of potato processing waste through yeast fermentation. Biores Technol. 2007;98(5):1138-43. doi:10.1016/j. biortech.2006.04.021.

Gervais P, Molin P. The role of water in solid-state fermentation. Biochem Eng J. 2003;13(2-3):85-101. doi:10.1016/\$1369-703X(02)00122-5.

Himmel ME, Ruth MF, Wyman CE. Cellulase for commodity products from cellulosic biomass. Curr Opin Biotechnol. 1999;10(4):358-64. doi:10.1016/ S0958-1669(99)80065-2.

Iyayi EA, Losel DM. Protein enrichment of cassava by- products through solid state fermentation by fungi. J Food Technol Africa. 2001;6(4):116-8.

Kongkiattikajorn J, Sornvoraweat B. Comparative study of bioethanol production from cassava peels by monoculture and co-culture of yeast. Kasetsart J (Nat Sci). 2011;274:268-74.

Kuhls K, Lieckfeld E, Börner T, Guého E. Molecular re-identification of human pathogenic Trichoderma isolates as T.longibrachiatum and T.citrinoviride. Med Mycol. 1999;37(1):25-33.

McCleary BV, Gibson TS, Mugford DC. Measurement of total starch in cereal products by amyloglucosidase-a-amylase method: Collaborative study. J AOAC Tnt. 1997;80:571-9.

Megazyme International. Total Starch (Amyloglucosidase/a-Amylase Method). 2014

Nagadesi PK, Arya A. effect of carbon and nitrogen on the growth of lignicolous fungi from rathanmahal wildlife sanctuary. Int J Sci Nature. 2013;4(2):237-45

Ofoefule AU, Uzodinma EO. Biogas production from blends of cassava (Manihot utilissima) peels with some animal wastes. Int J Phy Sci. 2009;4(7):398-402.

Onilude A. Effect of cassava cultivar, age and pretreatment processes of cellulase and xylanase production from cassava waste by Trichoderma harzanium. J Basic Microbiol. 1996;36(6):421-31.

Pandey A. Recent process developments in solid-state fermentation. Process Biochem. 1992;27:109-17.

Pandey A, Soccol CR. Economic utilization of crop residues for value addition: a Futuristic Approach. J Sci Ind Res. 2000;59(1):12-22.

Robinson T, Nigam P. Bioreactor design for protein enrichment of agricultural residues by solid state fermentation. Bioche Eng J. 2003;13(2-3):197-203. doi:10.1016/S1369-703X(02)00132-8.

Roussos S, Raimbault M, Prébois JP, Losane BK. Zymotis, a large scale solid state fermenter: design and Evaluation. Appl Biochem Biotechnol. 1993:42:37-52. 
Soccol CR, Vandenberghe LPS. Overview of applied solid-state fermentation in Brazil. Biochem Eng J. 2003;13(2-3):205-18. doi:10.1016/ S1369-703X(02)00133-X.

SRID-MoFA. (2011). Agriculture in Ghana: Facts and Figures. Ministry of Food and Agriculture Statistics Research and Information Directorate.

Tewe OO, Iyayi EA. Toxicanta of plant origin. In Cheeke PR (editors), Cyanogenic glucosided 2nd ed. 1989. CRS Press, p. 43-60.

Tivana LD (2012) Cassava Processing : Safety and Protein Fortification. Lund University.
Tudor D, Robinson SC, Cooper PA. The influence of moisture content variation on fungal pigment formation in spalted wood. Appl Microbiol Biotechnol Express. 2012;2(1):69. doi:10.1186/2191-0855-2-69.

Ugwuanyi JO, Harvey LM, McNeil B. Protein enrichment of corn cob heteroxylan waste slurry by thermophilic aerobic digestion using Bacillus stearothermophilus. Biores Technol. 2008;99(15):6974-85. doi:10.1016/j. biortech.2008.01.025.

\section{Submit your manuscript to a SpringerOpen ${ }^{\circ}$ journal and benefit from:}

- Convenient online submission

- Rigorous peer review

- Immediate publication on acceptance

- Open access: articles freely available online

- High visibility within the field

- Retaining the copyright to your article

Submit your next manuscript at $\gg$ springeropen.com 